\title{
Fish assemblages associated with Cymodocea nodosa and Caulerpa prolifera meadows in the shallow areas of the Mar Menor coastal lagoon
}

\author{
David Verdiell-Cubedo *, Francisco José Oliva-Paterna and Mar Torralva-Forero \\ Departamento de Zoología y Antropología, Universidad de Murcia, 30100 Murcia, España \\ *Corresponding author: verdiell@um.es
}

\begin{abstract}
Fish assemblages associated with Cymodocea nodosa and Caulerpa prolifera meadows in the shallow areas of the Mar Menor coastal lagoon

The present study investigates several biological parameters of the fish assemblages, mainly juvenile fishes and adults of small sized species, associated with the seagrass Cymodocea nodosa and the macroalga Caulerpa prolifera in the shallow littoral areas of the Mar Menor coastal lagoon. Results showed that $C$ nodosa seagrass meadows have a much higher number of fish species and considerably greater fish abundance and biomass than $\mathrm{Ca}$. prolifera meadows. Other community variables (diversity and evenness) did not show significant differences between both meadows.
\end{abstract}

Key words: Coastal lagoon, shallow habitats, juvenile fish, Mugilidae, Syngnathidae.

\section{RESUMEN}

Comunidades de peces asociadas a praderas de Cymodocea nodosa y Caulerpa prolifera en las zonas someras de la laguna costera del Mar Menor

En el presente estudio se investigaron diversos parámetros biológicos de las comunidades de peces, principalmente peces juveniles y adultos de especies de talla pequeña, asociadas a las praderas de la fanerógama acuática Cymodocea nodosa y la macroalga Caulerpa prolifera en las zonas someras litorales de la laguna costera del Mar Menor. Los resultados mostraron que las praderas de C. nodosa presentaron un mayor numero de especies y una mayor abundancia y biomasa de peces que las praderas de Ca. prolifera. Otras variables de la comunidad (diversidad y equitatividad) no mostraron diferencias significativas entre ambos tipos de praderas.

Palabras clave: Laguna costera, hábitats someros, peces juveniles, Mugilidae, Syngnathidae.

\section{INTRODUCTION}

Coastal lagoons are usually among those marine habitats with highest biological productivity providing abundant food resources and functioning as nursery areas for marine fish populations (Pérez-Ruzafa et al., 2004; Franco et al., 2006; Ribeiro et al., 2006). In addition, most lagoons are subjected to anthropogenic disturbances that lead to changes in the composition and distribution of flora and fauna species (Gamito et al., 2005).
The Mar Menor is a hypersaline coastal lagoon located in a semiarid region in the south-east of the Iberian Peninsula. Since the 1970's it has suffered strong environmental changes following widening of the connecting channels that have caused a decrease in salinity from $50 \%$ o$52 \%$ to the present levels. Moreover, regular and intermittent watercourses flow into the lagoon, draining a large intensive agricultural area and leading to an important input of agrochemicals (Pérez-Ruzafa et al., 2005). Its coastline is also 
densely populated and affected by a variety of human activities (urban development, the construction of pleasure marinas, artificial beaches, etc.), although there are still some associated wetlands (industrial salt ponds and natural marshlands) that have an important ecological and natural value and which have been given national and international protection status (Martínez et al., 2005). In addition, recent studies dealing with the Mar Menor coastal lagoon fish assemblages pointed to the importance of shallow littoral areas as nursery habitats for juvenile fish as well as adult individuals of small sized species (Oliva-Paterna et al., 2006).

Environmental degradation has led to changes in the distribution of the benthic macrophytes of the lagoon. Before 1970, its bottom was covered principally by scattered meadows of Cymodocea nodosa (Ucria) Ascherson and Zostera marina Linnaeus (Pérez-Ruzafa et al., 2005) sea grasses. At the present time, a dense monospecific meadow of the invasive macroalga Caulerpa prolifera (Forsskal) Lamouroux covers more than $80 \%$ of the bottom, and $C$. nodosa is restricted to very small patches in the shallowest areas of the lagoon.

The spread of $C a$. prolifera has created several negative effects on the sediment characteristics, such an increase in its organic matter content and low oxygen concentration, and the modification of fish assemblages in the lagoon (Lloret et al., 2005; Pérez-Ruzafa et al., 2005; Pérez-Ruzafa et al., 2006).

Therefore, the aim of this work was to study the differences in several biological parameters of the fish assemblages, mainly juvenile fishes and adults of small species, between areas with homospecific meadows of Caulerpa prolifera and Cymodocea nodosa located in the shallow and littoral areas of the lagoon.

\section{MATERIALS AND METHODS}

\section{Study area}

The present study was carried out in the shallow littoral areas (maximum depth $\leq 100 \mathrm{~cm}$ ) of the Mar Menor coastal lagoon. It is one of the largest coastal lagoons in the Mediterranean region and Europe, with a surface area of $135 \mathrm{~km}^{2}$, an average depth of $4 \mathrm{~m}$ and it is separated from the Mediterranean Sea by a $22 \mathrm{~km}$ long sand bar with three narrow channels connecting it with the open sea. The lagoon shows a salinity range of $39 \%$ $45 \%$ and the temperature varies from $10^{\circ} \mathrm{C}$ in winter to $32^{\circ} \mathrm{C}$ in summer.

Sampling sites are characterised by soft substrates (principally muddy and sandy bottoms) and isolated patches of submerged vegetation, mainly meadows of the seagrass Cymodocea nodosa and the macroalga Caulerpa prolifera.

\section{Sampling methods}

The sampling was carried out on a seasonal basis, during the summer (July) and autumn (October) of 2003, and the winter (February) and spring (May) of 2004.

Samples were collected using a $10 \mathrm{~m}$ long beach seine ( $2 \mathrm{~mm}$ mesh size) in the shallow areas of the lagoon with homospecific meadows of $C$. nodosa and $C a$. prolifera. The sampling unit (a haul) consisted of the area swept $\left(160 \mathrm{~m}^{2}\right)$ by the beach seine. We obtained a total of 44 sampling units during the study period, 26 in the C. nodosa meadows ( 8 in summer, 6 in autumn, 10 in winter and 2 in spring) and 19 in the $C a$. prolifera meadows ( 8 in summer, 2 in autumn, 7 in winter and 2 in spring).

All fish collected per haul were preserved in $7 \%$ formaldehyde, identified at species level in the laboratory according to Whitehead et al. (1986) and Arias \& Drake (1990) and classified in relation to their vertical distribution adapted from Elliot \& Dewailly (1995): (B) benthic and (EB) epibenthic species.

The total relative abundance, total relative biomass, benthic species relative abundance, benthic species relative biomass, epibenthic species relative abundance and epibenthic species relative biomass were determined for the fish assemblage at each sampling unit. These were respectively expressed as catch per unit of effort (CPUE) and biomass per unit of effort (BPUE):

CPUE $=$ fish number/haul area covered $\left(160 \mathrm{~m}^{2}\right)$ 
Table 1. Mean cover and volume ( \pm S.E.) for Cymodocea nodosa and Caulerpa prolifera meadows during the study period. Cobertura y volumen promedio ( \pm E.S.) de las praderas de Cymodocea nodosa y Caulerpa prolifera durante el periodo de estudio.

\begin{tabular}{|ccccc|}
\hline \multirow{2}{*}{ Season } & \multicolumn{2}{c|}{ Cymodocea nodosa } & \multicolumn{2}{c|}{ Caulerpa prolifera } \\
\cline { 2 - 5 } & Cover \pm S.E. & Volume \pm S.E. & Cover \pm S.E. & Volume \pm S.E. \\
\hline Summer & $75.00 \pm 5.67$ & $3.56 \pm 0.22$ & $48.75 \pm 9.53$ & $2.75 \pm 0.28$ \\
\hline Autumn & $37.50 \pm 10.39$ & $1.42 \pm 0.20$ & $62.50 \pm 17.50$ & $2.00 \pm 0.50$ \\
\hline Winter & $45.95 \pm 8.21$ & $2.20 \pm 0.26$ & $51.43 \pm 7.05$ & $2.29 \pm 0.21$ \\
\hline Spring & $47.50 \pm 12.50$ & $2.00 \pm 0$ & $17.50 \pm 3.54$ & $2.00 \pm 0$ \\
\hline
\end{tabular}

BPUE = fish biomass $(\mathrm{g}) /$ haul area covered $\left(160 \mathrm{~m}^{2}\right)$

Each sampling unit was characterized by environmental variables related to submerged vegetation structure: submerged vegetation cover (\%) and submerged vegetation volume. The assessment of these variables was made visually, the first recorded as the area percentage covered by submerged vegetation at each haul and the second as an ordinate categorical variable from 0 (low density of meadows) to 5 (high density of meadows).

In addition, the species richness $(S)$, Shannon diversity $\left(H^{\prime}=-\sum P_{i} \ln \left(P_{i}\right)\right)$ and Pielou's evenness $\left(J^{\prime}=H^{\prime} / \ln S\right)$, describing the structure of fish assemblage, were calculated for each sampling unit.

\section{Statistical analyses}

Analysis of variance (one way ANOVA) was used to test differences in the cover and volume of the meadows.

A two-way factorial analysis of variance (ANOVA) was used to test for differences in the total CPUE, total BPUE, benthic species CPUE, benthic species BPUE, epibenthic species CPUE, epibenthic species BPUE, species richness, Shannon diversity and Pielou's evenness of the fish assemblages. The independent variables were vegetation species ( $C$. nodosa and $C a$. prolifera) and season (summer, autumn, winter and spring), both considered as fixed factors (Quinn $\&$ Keough 2002). Analysis was performed on the transformed data $(\ln (x+1))$ with significance level of $P<0.05$.

The statistical analyses were performed using the SPSS ${ }^{\circledR}$ statistical package.
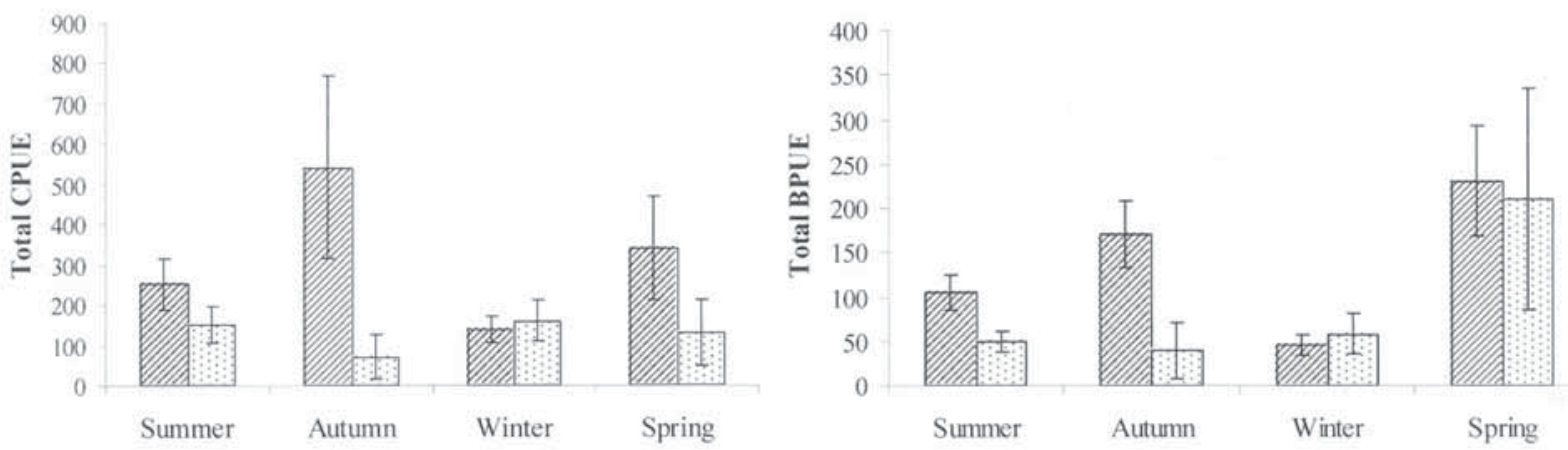

Figure 1. Mean relative abundance (CPUE \pm S.E.) and mean relative biomass (BPUE \pm S.E.) of all fish species over Cymodocea nodosa (四) and Caulerpa prolifera (國) meadows during the study period. Abundancia relativa promedio (CPUE \pm E.S.) y biomasa relativa promedio (BPUE \pm E.S.) del total de especies de peces en las praderas de Cymodocea nodosa (四) y Caulerpa prolifera (圆) durante el periodo de estudio. 
Table 2. List of families and species caught over Cymodocea nodosa and Caulerpa prolifera meadows in the Mar Menor coastal lagoon, mean relative abundance (CPUE), mean relative biomass (BPUE), and vertical distribution classification. Listado de las familias y especies capturadas sobre las praderas de Cymodocea nodosa y Caulerpa prolifera en la laguna costera del Mar Menor, abundancia relativa promedio (CPUE), biomasa relativa promedio (BPUE), y clasificación en función de su distribución vertical.

\begin{tabular}{|c|c|c|c|c|c|c|}
\hline \multirow{2}{*}{ Family } & \multirow{2}{*}{ Species } & \multicolumn{2}{|c|}{ Cymodocea nodosa } & \multicolumn{2}{|c|}{ Caulerpa prolifera } & \multirow{2}{*}{$\begin{array}{c}\text { Vertical } \\
\text { distribution }\end{array}$} \\
\hline & & $\begin{array}{l}\text { CPUE } \\
\end{array}$ & BPUE & CPUE & BPUE & \\
\hline \multicolumn{7}{|l|}{ Anguillidae } \\
\hline & Anguilla anguilla & 0 & 0 & 0.05 & 0.68 & B \\
\hline \multicolumn{7}{|l|}{ Atherinidae } \\
\hline & Atherina boyeri & 30.65 & 13.00 & 28.26 & 16.30 & EB \\
\hline \multicolumn{7}{|l|}{ Bleniidae } \\
\hline & Lipophrys dalmatinus & 0.08 & 0.05 & 0.53 & 0.15 & B \\
\hline & Salaria pavo & 4.19 & 5.45 & 5.00 & 4.22 & B \\
\hline \multicolumn{7}{|l|}{ Callionymidae } \\
\hline & Callionymus pusillus & 0.23 & 0.17 & 0 & 0 & B \\
\hline \multicolumn{7}{|l|}{ Cyprinodontidae } \\
\hline & Aphanius iberus & 19.00 & 4.10 & 1.21 & 0.26 & EB \\
\hline \multicolumn{7}{|l|}{ Gobiidae } \\
\hline & Pomatoschistus marmoratus & 53.77 & 17.38 & 38.63 & 7.28 & $\mathrm{~B}$ \\
\hline & Gobius cobitis & 1.62 & 4.86 & 0.79 & 1.53 & $\mathrm{~B}$ \\
\hline & Gobius paganellus & 0.19 & 0.30 & 0 & 0 & B \\
\hline & Gobius niger & 0.89 & 1.90 & 0.16 & 0.62 & B \\
\hline \multicolumn{7}{|l|}{ Labridae } \\
\hline & Symphodus cinereus & 0.73 & 3.91 & 0.32 & 0.51 & EB \\
\hline \multicolumn{7}{|l|}{ Moronidae } \\
\hline & Dicentrarchus labrax & 0.15 & 0.02 & 0 & 0 & $\mathrm{~EB}$ \\
\hline & Dicentrarchus punctatus & 0.04 & 0.29 & 0.21 & 0.32 & EB \\
\hline \multicolumn{7}{|l|}{ Mugilidae } \\
\hline & Liza aurata & 58.19 & 20.01 & 29.42 & 13.91 & EB \\
\hline & Liza saliens & 79.85 & 21.38 & 14.00 & 17.21 & EB \\
\hline & Liza ramado & 0.38 & 0.35 & 0.58 & 0.10 & EB \\
\hline & Chelon labrosus & 0.19 & 0.25 & 0 & 0 & EB \\
\hline & Mugil cephalus & 3.96 & 0.60 & 0 & 0 & EB \\
\hline \multicolumn{7}{|l|}{ Soleidae } \\
\hline & Solea vulgaris & 0 & 0 & 0.05 & 0.12 & B \\
\hline \multicolumn{7}{|l|}{ Sparidae } \\
\hline & Diplodus puntazzo & 1.92 & 1.00 & 0.21 & 1.05 & EB \\
\hline & Diplodus sargus & 1.50 & 0.09 & 0 & 0 & EB \\
\hline & Sparus aurata & 3.50 & 0.86 & 20.58 & 3.16 & $\mathrm{~EB}$ \\
\hline & Sarpa salpa & 0.54 & 0.52 & 0 & 0 & $\mathrm{~EB}$ \\
\hline \multicolumn{7}{|l|}{ Syngnathidae } \\
\hline & Hippocampus guttulatus & 0.08 & 0.03 & 0.05 & 0.02 & EB \\
\hline & Syngnathus abaster & 19.89 & 5.30 & 4.16 & 0.83 & EB \\
\hline & Syngnathus typhle & 0.15 & 0.20 & 0 & 0 & $\mathrm{~EB}$ \\
\hline Epibenthic species & & 220.72 & 71.89 & 94.00 & 39.20 & \\
\hline Benthic species & & 60.97 & 30.11 & 46.4 & 14.31 & \\
\hline Total & & 281.69 & 102.00 & 140.4 & 53.51 & \\
\hline Total species & & 24 & & 18 & & \\
\hline
\end{tabular}




\section{RESULTS}

The seasonal fluctuation of the cover and volume of Cymodocea nodosa and Caulerpa prolifera meadows is shown in Table 1. In $C$. prolifera meadows, no significant differences were observed through the study period (ANOVA cover, $F=1.518, P=0.251$; ANOVA volume, $F=1.229, P=0.334$ ), although higher cover and volume were recorded in summer and autumn, respectively. On the other hand, C. nodosa showed significant seasonal differences (ANOVA cover, $F=3.773, P<0.05$; ANOVA volume, $F=3.773$, $P<0.001)$. Higher cover and volume was recorded in summer and lower values in winter.

The overall fish species abundance and biomass were higher in the $C$. nodosa than $C a$. prolifera meadows (Table 2), with significant differences in mean total CPUE and mean total BPUE between $C$. nodosa and $C a$. prolifera meadows (Table 3 and Fig. 1). There was also a significant seasonal difference in mean total BPUE, which was higher during spring for both meadow species (Table 3 and Fig. 1).

Overall abundance and biomass of the benthic species were higher in the $C$. nodosa than $C a$. prolifera meadows (Table 2). Their mean CPUE and mean BPUE were also significantly higher in the $C$. nodosa meadows (Table 3 and Fig. 2).

There was also a significant seasonal variation in benthic species abundance and biomass, both being higher in the $C$. nodosa meadows in autumn and the $C a$. prolifera meadows in summer (Table 3 and Fig. 2).

With regard to epibenthic species, the overall abundance and biomass were higher in the C. nodosa meadows (Table 2). Although no significant differences were obtained for mean epibenthic species BPUE, their mean CPUE was significantly higher in the $C$. nodosa than Ca. prolifera meadows (Table 3 and Fig. 3 ). In addition, there was a significant effect of season on mean epibenthic species BPUE (Table 3 and Fig. 2). Of note are the higher abundance and biomass of the mugilidae species Liza aurata and $L$. saliens, the syngnathidae

Table 3. Results of two-way ANOVA tests for differences between seasons and meadow species in total CPUE and BPUE, benthic species CPUE and BPUE, epibenthic species CPUE and BPUE, species richness (S), Shannon diversity $\left(H^{\prime}\right)$ and Pielou's evenness $\left(J^{\prime}\right)$. Resultados del test ANOVA de dos vías empleado para testar las diferencias entre las estaciones del año y las especies de pradera en las CPUE y BPUE totales, CPUE y BPUE de las especies bentónicas, CPUE y BPUE de las especies epibentónicas, riqueza de especies $(S)$, diversidad $\left(H^{\prime}\right)$ y equitatividad $\left(J^{\prime}\right)$.

\begin{tabular}{|c|c|c|c|c|c|c|c|}
\hline \multirow{2}{*}{ Effects } & \multirow{2}{*}{$\mathrm{df}$} & \multicolumn{2}{|c|}{ Total abundance } & \multicolumn{2}{|c|}{ Total biomass } & \multicolumn{2}{|c|}{ Benthic species abundance } \\
\hline & & $F$ & $P$ & $F$ & $P$ & $F$ & $P$ \\
\hline Season & 3 & 0.260 & 0.854 & 5.001 & $<0.01$ & 4.504 & $<0.01$ \\
\hline Meadow species & 1 & 7.505 & $<0.01$ & 4.870 & $<0.05$ & 4.831 & $<0.05$ \\
\hline Season x Meadow species & 3 & 1.994 & 0.132 & 1.800 & 0.164 & 2.431 & 0.081 \\
\hline \multirow{2}{*}{ Effects } & \multirow{2}{*}{ df } & \multicolumn{2}{|c|}{ Benthic species biomass } & \multicolumn{2}{|c|}{ Epibenthic species abundance } & \multicolumn{2}{|c|}{ Epibenthic species biomass } \\
\hline & & $F$ & $P$ & $F$ & $P$ & $F$ & $P$ \\
\hline Season & 3 & 8.85 & $<0.001$ & 0.824 & 0.489 & 3.464 & $<0.05$ \\
\hline Meadow species & 1 & 5.387 & $<0.05$ & 6.026 & $<0.05$ & 2.804 & 0.102 \\
\hline Season x Meadow species & 3 & 1.709 & 0.182 & 1.822 & 0.160 & 1.783 & 0.167 \\
\hline \multirow{2}{*}{ Effects } & \multirow{2}{*}{ df } & \multicolumn{2}{|c|}{$S$} & \multicolumn{2}{|c|}{$H^{\prime}$} & \multicolumn{2}{|c|}{$J^{\prime}$} \\
\hline & & $F$ & $P$ & $F$ & $P$ & $F$ & $P$ \\
\hline Season & 3 & 3.341 & $<0.05$ & 2.347 & 0.089 & 0.854 & 0.474 \\
\hline Meadow species & 1 & 11.177 & $<0.01$ & 0.439 & 0.512 & 0.444 & 0.509 \\
\hline Season x Meadow species & 3 & 1.078 & 0.370 & 2.600 & 0.067 & 2.542 & 0.071 \\
\hline
\end{tabular}



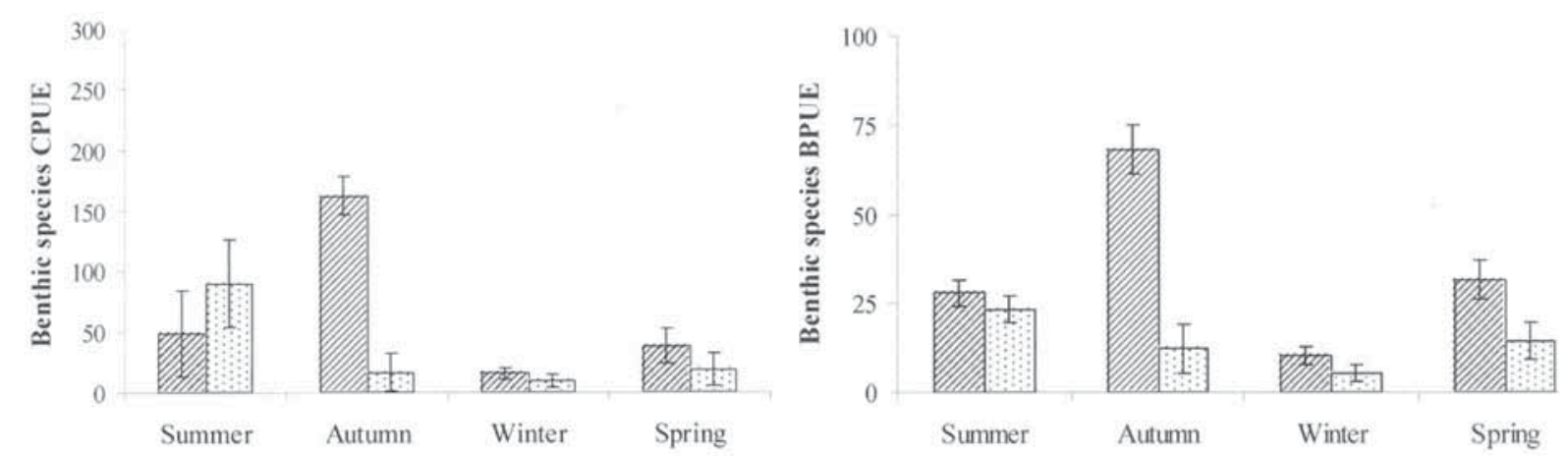

Figure 2. Mean relative abundance (CPUE \pm S.E.) and mean relative biomass (BPUE \pm S.E.) of benthic fish species over Cymodocea nodosa (四) and Caulerpa prolifera (國) meadows during the study period. Abundancia relativa promedio (CPUE \pm E.S.) y biomasa relativa promedio (BPUE \pm E.S.) de las especies de peces bentónicos en las praderas de Cymodocea nodosa (四) y Caulerpa prolifera (圆) durante el periodo de estudio.

species Syngnathus abaster and the threatened cyprinodontidae species Aphanius iberus in the C. nodosa meadows, while Sparus aurata abundance and biomass were higher in the $C a$. prolifera meadows (Table 2).

The total number of species and mean species richness were higher in the $C$. nodosa than in $C a$. prolifera meadows (Tables 2 and 3 ). In addition, there was a significant effect of season on mean species richness; which was higher during spring in the $C$. nodosa and during autumn in the $C a$. prolifera meadows (Table 3 and Fig. 4).

The Shannon diversity index $\left(H^{\prime}\right)$ and Pielous' evenness $\left(J^{\prime}\right)$ did not differ between meadow species and seasons (Table 3 and Fig. 4).

\section{DISCUSSION}

Many studies world-wide have demonstrated that vegetated habitats often support a greater diversity and abundance of juvenile fish (Guidetti, 2000; Paterson \& Whitfield, 2000; Lazzari et al., 2003; Nakamura \& Mitsuhiko, 2004; Ribeiro et $a l ., 2006)$. This pattern is due to the high structural complexity and productivity of vegetated systems that provide protection against predators and abundant food resources (i.e. higher invertebrate prey density) (Bell \& Pollard, 1989).

The vegetated habitats sampled in the present study were undoubtedly important areas for fish assemblages, especially for juvenile fishes. A to-
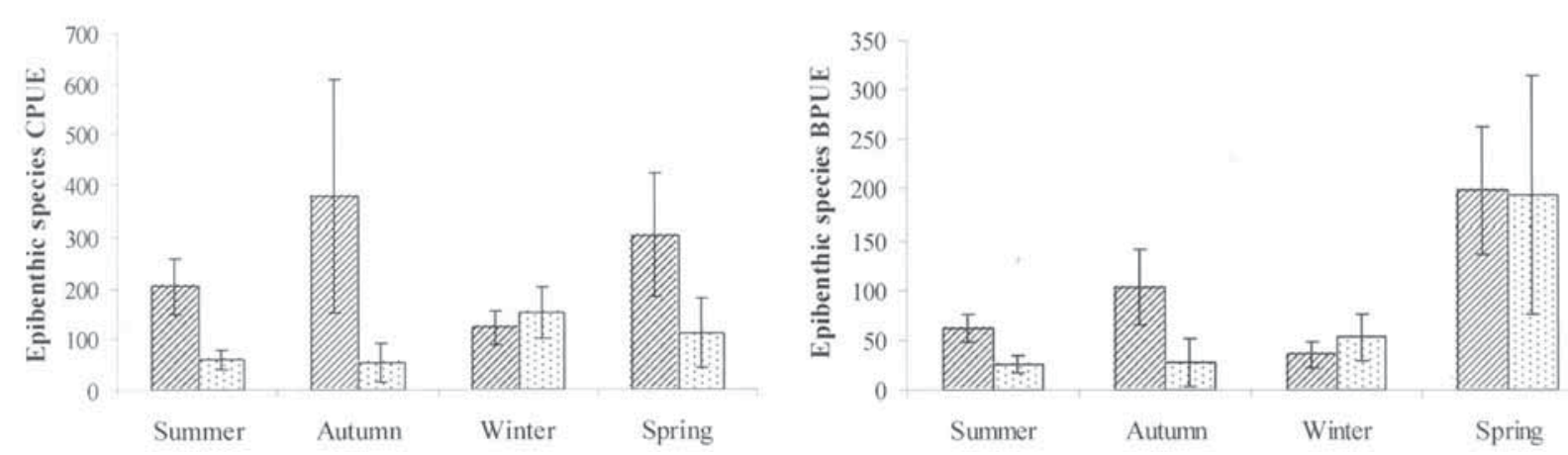

Figure 3. Mean relative abundance (CPUE \pm S.E.) and mean relative biomass (BPUE \pm S.E.) of epibenthic fish species over Cymodocea nodosa (ש) and Caulerpa prolifera (國) meadows during the study period. Abundancia promedio (CPUE \pm E.S.) y biomasa promedio (BPUE \pm E.S.) de especies de peces epibentónicos en las praderas de Cymodocea nodosa (四) y Caulerpa prolifera (國) durante el periodo de estudio. 

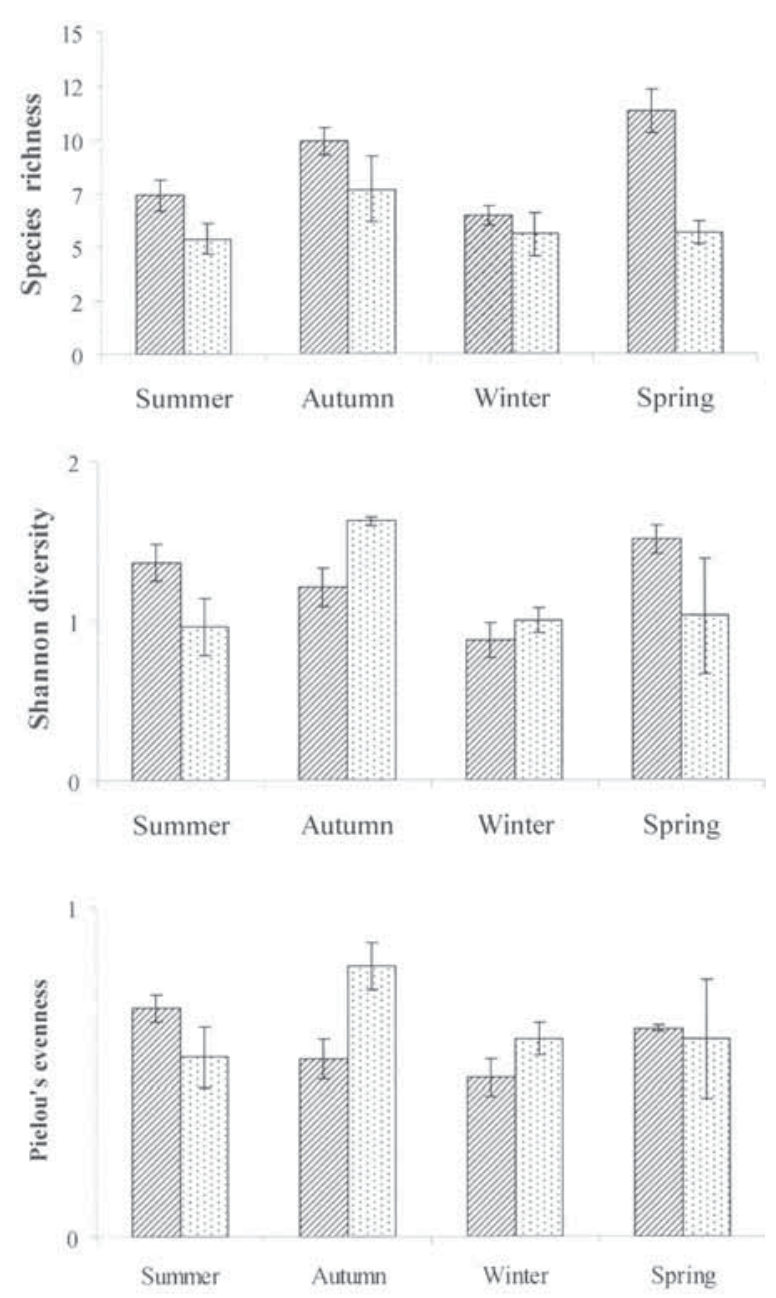

Figure 4. Mean species richness ( \pm S.E.), mean diversity, $( \pm$ S.E.) and mean evenness ( \pm S.E.) over Cymodocea nodosa (四) and Caulerpa prolifera (圖) meadows during the study period. Riqueza de especies promedio ( \pm E.S.), diversidad promedio $( \pm$ E.S.) y equitatividad promedio $( \pm$ E.S.) en las praderas de Cymodocea nodosa (四) y Caulerpa prolifera (畕) durante el periodo de estudio.

tal of 26 fish species were recorded in the vegetated shallow areas of the Mar Menor during the study period, which represents $58 \%$ of the fish species cited in the shallow littoral areas of the lagoon (Oliva-Paterna et al., 2006). Moreover, $73 \%$ of the species caught are among the species that form the main targets for commercial fisheries in the lagoon and adjacent coastal areas, or represent species of conservation interest.

In addition, we demonstrated that the fish assemblage in the $C$. nodosa seagrass meadows has a much higher number of species and considerably greater fish abundance and biomass than $C a$. prolifera meadows. These results suggest that $C$. nodosa meadows offered better conditions for the settlement of juvenile and adult fishes, probably due to differences in the structural complexity and food availability between seagrass and macroalgal habitats.

It is well documented that Caulerpa species produce repulsive and toxic secondary metabolites, like caulerpenine, against grazer and epiphytic organisms (Sánchez-Moyano et al., 2001; Jung et al., 2002; Davis et al., 2005). In addition, the settlement of dense Ca. prolifera meadows produces important and negative changes in the sediment characteristics through the accumulation of organic matter and the later appearance of anoxic conditions and the production of toxic acid volatile sulphides (Lloret et al., 2005; Pérez-Ruzafa et al., 2005). Despite such negative effects, several studies have demonstrated that $C a$. prolifera meadows support substantial invertebrate macrofaunal communities although such communities are not as rich and structured as in the seagrass meadows (Sánchez-Moyano et al., 2001; Rueda \& Salas, 2003; López et al., 2006).

On the other hand, some authors remarked on the importance of $C$. nodosa seagrass with regard to its higher abundance and diversity of invertebrate fauna (Sánchez-Jerez et al., 1999; Marín-Guirao et al., 2005).

It is possible that, due to the higher density of $\mathrm{Ca}$. prolifera meadows compared with the scarce seagrass meadows of $C$. nodosa, fish may not be able to obtain food so successfully; in addition, the availability of space for fish may be reduced. This hypothesis is consistent with the conclusions presented by several authors comparing other seagrass species, who observed differences in fish abundance and species composition related with changes in the structural architecture of the seagrasess (Guidetti, 2000; Guidetti \& Bussotti, 2000; MacArthur \& Hyndes, 2001; Hyndes et al., 2003).

It is interesting to note the differences observed in the abundance and biomass of Aphanius iberus. This endangered species shows preference for vegetated habitats which are very important for its reproduction and feeding 
(Oliva-Paterna et al., 2006). The results obtained highlight that $C$. nodosa seagrass meadows offered much more favourable conditions for the settlement of A. iberus.

In the same way, patterns in habitat preferences of syngnathidae species, like $S$. abaster, are related with their morphology and foraging strategy (Kendrick \& Hyndes, 2003; Curtis \& Vincent, 2005). Our results suggest that $S$. abaster is morphologically better adapted to the sparse and narrower leaves of $C$. nodosa since its abundance and biomass were higher in this seagrass species.

It is to note the higher abundance and biomass of Liza aurata and L. saliens in the $C$. nodosa than in Ca. prolifera meadows. This situation was probably related with their foraging strategy, which consists of foraging on detritus and benthic invertebrates (Fernández-Delgado et al., 2000; Verdiell-Cubedo et al., 2007). The higher density of the Caulerpa meadow and its negative effects on the sediment characteristics could negatively affect the foraging effectiveness of these Mugilidae species. In fact, the spread of $\mathrm{Ca}$. prolifera has been considered one of the causes of the strong reduction in Mugilidae fisheries in the Mar Menor coastal lagoon (PérezRuzafa \& Marcos, 1987).

Finally, the seasonal differences observed for the mean cover and volume of the $C$. nodosa and $\mathrm{Ca}$. prolifera meadows seems to be consistent with the typical dynamics of these species, which strongly respond to seasonal forces (Terrados \& Ros, 1992; Sánchez-Moyano et al., 2001; Agostini et al., 2003). In this sense, the significant seasonal variations of the benthic fish fauna (CPUE and BPUE), epibenthic species BPUE and species richness could be affected by the marked annual dynamics of the above-ground compartment of such meadow species (Tuya et al., 2006), apart from the seasonality of the breeding and juvenile fish recruitment periods.

\section{ACKNOWLEDGEMENTS}

The authors are grateful to Asunción Andreu, Pedro A. Miñano, Andrés Egea, and members of the Department of Zoology of the University of Murcia for their help in field sampling; and Philip Thomas for the English revision. Part of this research was supported by the Environmental Service of the Autonomous Government of Murcia, Spain.

\section{REFERENCES}

AGOSTINI, S., G. PERGENT \& MARCHAND B. 2003. Growth and primary production of Cymodocea nodosa in a coastal lagoon. Aquat. Bot., 76: 185-193.

ARIAS, A. M. \& P. DRAKE. 1990. Estados alevines y juveniles de la ictiofauna en los caños de las salinas de la bahía de Cádiz. Instituto de Ciencias Marinas de Andalucía. CSIC, Cádiz. 163 pp.

BELL, J. D. \& D. A. POLLARD. 1989. Ecology of fish assemblages and fisheries associated with seagrasses. In: Biology of seagrasses. A. W. D. Larkum, A. J. McComb, S. A. Shepherd (eds.): 536-564. Elsevier. Amsterdam.

CURTIS, J. M. R. \& A. C. J. VINCENT. 2005. Distribution of sympatric seahorse species along a gradient of habitat complexity in a seagrassdominated community. Marine Ecology Progress Series, 291: 81-91.

DAVIS, A. R., K. BENKENFORFF \& D. W. WARD. 2005. Responses of common SE Australian herbivores to three suspected invasive Caulerpa spp. Marine Biology, 146: 859-868.

ELLIOTT, M. \& F. DEWAILLY. 1995. The structure and components of European stuaries assemblages. Netherlands Journal of Aquatic Ecology, 29: 397-417.

FERNÁNDEZ-DELGADO, C., P. DRAKE, A. M. ARIAS \& D. GARCIA. 2000. Peces de Doñana y su entorno. Organismo Autónomo de Parques Nacionales. Ministerio de Medio Ambiente, Madrid. 272 pp.

FRANCO, A., P. FRANZOI, S. MALAVASI, F. RICCATO, P. TORRICELLI \& D. MAINARDI. 2006. Use of shallow water habitats by fish assemblages in a Mediterranean coastal lagoon. Estuarine, Coastal and Shelf Science, 66: 67-83.

GAMITO, S., J. GILABERT, C. MARCOS-DIEGO \& A. PÉREZ-RUZAFA. 2005. Effects of changing environmental conditions on lagoon ecology. In: Coastal lagoons. Ecosystem processes and modelling for sustainable use and development. I. 
E. Gönenç \& J. P. Wolflin (eds.): 193-229. CRC Press, Boca Ratón.

GUIDETTI, P. 2000. Differences among fish assemblages associated with nearshore Posidonia oceanica seagrass beds, rocky-algal reefs and unvegetated sand habitats in the Adriatic Sea. Estuarine, Coastal and Shelf Science, 50: 515-529.

GUIDETTI, P. \& S. BUSSOTTI. 2002. Effects of seagrass canopy removal on fish in shallow Mediterranean seagrass (Cymodocea nodosa and Zostera noltii) meadows: a local-scale approach. Marine Biology, 140: 445-453.

HYNDES, G. A., A. J. KENDRICK, L. D. MACARTHUR \& E. STEWART. 2001. Differences in the species- and size-composition of fish assemblages in three distinct seagrass habitats with differing plant and meadow structure. Marine Biology, 142: 1195-1206.

JUNG, V., T. THIBAUT, A. MEINESZ \& G. POHNERT. 2002. Comparison of the wound-activated transfromation of caulerpenyne by invasive and noninvasive Caulerpa species of the Mediterranean. J. Chem. Ecol., 28 (10): 2091-2105.

KENDRICK, A. J. \& G. A. HYNDES. 2003. Patterns in the abundance and size-distribution of syngnathid fishes among habitats in a seagrassdominated marine environment. Estuarine, Coastal and Shelf Science, 57: 631-640.

LAZZARI, M. A., S. SHERMAN \& J. K. KANWIT. 2003. Nursery use of shallow habitats by epibenthic fishes in Maine nearshore waters. Estuarine, Coastal and Shelf Science, 56: 73-84.

LÓPEZ, I., A. RODRÍGUEZ \& J. GARCÍA-RASO. 2006. Seasonal variation and structure of a decapod (Crustacea) assemblage living in a Caulerpa prolifera meadow in Cádiz Bay (SW Spain). Estuarine, Coastal and Shelf Science, 66: 624-633.

LLORET, J., A. MARÍN, L. MARÍN-GUIRAO \& J. VELASCO. 2005. Changes in macrophytes distribution in a hypersaline coastal lagoon associated with the development of intensively irrigated agriculture. Ocean \& Coastal Management, 48: 828842.

MACARTHUR, L. D. \& G. A. HYNDES. 2001. Differential use of seagrass assemblages by a asuite of Odacid species. Estuarine, Coastal and Shelf Science, 52: 79-90.

MARÍN-GUIRAO, L., A. MARÍN, J. LLORET, E. MARTÍNEZ-LÓPEZ \& A. J. GARCÍA-FERNÁNDEZ. 2005. Effects of mining wastes on a seagrass ecosystem: metal accumulation and bioavailability, seagrass dynamics and associated community structure. Marine Environmental Research, 60: 317-337.

MARTÍNEZ, J., M. A. ESTEVE, F. ROBLEDANO, M. T. PARDO \& M. F. CARREÑO. 2005. Aquatic birds as bioindicators of trophic changes and ecosystem deterioration in the Mar Menor lagoon (SE Spain). Hydrobiologia, 550: 221-235.

NAKAMURA, Y. \& S. MITSUHIKO. 2004. Overlaps in habitat use of fishes between a seagrass bed and adjacent coral and sand areas at Amitori Bay, Iriomote Island, Japan: Importance of the seagrass bed as juvenile habitat. Fisheries Science, 70: 788803.

OLIVA-PATERNA, F. J., M. TORRALVA \& C. FERNÁNDEZ-DELGADO 2006. Threatened fishes of the world: Aphanius iberus (Cuvier \& Valenciennes, 1846) (Cyprinodontidae). Environmental Biology of Fishes, 75: 307-309.

OLIVA-PATERNA, F. J., A. ANDREU, P. A. MIÑANO, D. VERDIELL, A. EGEA, J. A. DE MAYA, A. RUIZ-NAVARRO, J. GARCÍA-ALONSO, C. FERNÁNDEZ-DELGADO \& M. TORRALVA. 2006. YOY fish species richness in the littoral shallows of the mesosaline coastal lagoon (Mar Menor, Mediterranean coast of the Iberian Peninsula). Journal of Applied Ichthyology, 22: 235-237.

PATERSON, A. W. \& A. K. WHITFIELD. 2000. The ichthyofauna associated with an intertidal creek and adjacent eelgrass beds in the Kariega estuary, South Africa. Environmental Biology of Fishes, 58: 145-156.

PÉREZ-RUZAFA, A. \& C. MARCOS. 1987. Los sustratos arenosos y fangosos del Mar Menor (Murcia), su cubierta vegetal y su posible relación con la disminución del mújol en la laguna. Cuadernos Marisqueros Publicación Técnica, 11: 111-123.

PÉREZ-RUZAFA, A., J. I. QUISPE-BECERRA, J. A. GARCÍA-CHARTON \& C. MARCOS. 2004. Composition, structure and distribution of the ichthyoplankton in a Mediterranean coastal lagoon. J.Fish Biol., 64: 202-218.

PÉREZ-RUZAFA, A., C. MARCOS \& J. GILABERT. 2005. The ecology of the Mar Menor coastal lagoon: a fast changing ecosystem under human pressure. In: Coastal lagoons. Ecosystem processes and modelling for sustainable use and development. I. E. Gönenç \& J. P. Wolflin (eds.): 392-422. CRC Press, Boca Ratón. 
PÉREZ-RUZAFA A., J. A. GARCÍA-CHARTON, E. BARCALA \& C. MARCOS. 2006. Changes in benthic fish assemblages as a consequence of coastal works in a coastal lagoon: The Mar Menor (Spain, Western Mediterranean). Marine Pollution Bulletin, 53: 107-120.

QUINN, G. \& M. KEOUGH. 2002. Experimental design and data analysis for biologists. Cambridge University Press, Cambridge. 556 pp.

RIBEIRO J., L. BENTES, R. COELHO, J. M. S. GONÇALVES, P. G. LINO, P. MONTEIRO \& K. ERZINI. 2006. Seasonal, tidal and diurnal changes in fish assemblages in the Ria Formosa lagoon (Portugal). Estuarine, Coastal and Shelf Science, 67: 461-474.

RUEDA, J. L. \& C. SALAS. 2003. Seasonal variation of a molluscan assemblage living in a $\mathrm{Cau}$ lerpa prolifera meadow within the inner Bay of Cádiz (SW Spain). Estuarine, Coastal and Shelf Science, 57: 909-918.

SÁNCHEZ-JEREZ, P., C. BARBERÁ-CEBRIÁN \& A. A. RAMOS-ESPLÁ. 1999. Comparison of the epifauna spatial distribution in Posidonia oceanica, Cymodocea nodosa ad unvegetated bottoms: Importance of meadow edges. Acta
Oecologica, 20(4): 391-405.

SÁNCHEZ-MOYANO, J. E., F. J. ESTACIO, E. M. GARCÍA-ADIEGO \& J. C. GARCÍA-GÓMEZ. 2001. Effect of the vegetative cycle of Caulerpa prolifera on the spatio-temporal variation of invertebrate macrofauna. Aquat. Bot., 70: 163-174.

TERRADOS, J. \& J. D. ROS. 1992. Growth and primary production of Cymodocea nodosa (Ucria) Ascherson in a Mediterranean coastal lagoon: The Mar Menor (SE Spain). Aquat. Bot., 43: 63-74.

TUYA, F., J. A. MARTÍN \& A. LUQUE. 2006. Seasonal cycle of a Cymodocea nodosa seagrass meadow and the associated ichthyofauna at Playa Dorada (Lanzarote, Canary Islands, eastern Atlantic). Ciencias Marinas, 32(4): 695-704.

VERDIELL-CUBEDO, D., A. EGEA-SERRANO, F. J. OLIVA-PATERNA \& M. TORRALVA. 2007. Biología trófica de los juveniles del género Liza (Pisces: Mugilidae) en la laguna costera del Mar Menor (SE Península Ibérica). Limnetica, 26 (1): 67-74.

WHITEHEAD, P. J. P., M. L. BAUCHOT, J. C. HUREAU, J. NIELSEN \& E. TORTONESE. 1986. Fishes of the North-eastern Atlantic and the Mediterranean, Vol. 3. UNESCO, Paris. 1473 pp. 